pollution and the wasteful exploitation and consumption of resources and energy. WWF's ultimate goal is to stop, and eventually reverse, the accelerating degradation of our planet's natural environment, and to help build a future in which humans live in harmony with nature.

Address: Avenue du Mont-Blanc, CH-1196 Gland,

Switzerland.

Website: http://www.panda.org

Director General: James P. Leape (USA).

President Emeritus: HRH The Prince Philip, Duke of

Edinburgh.

President: Chief Emeka Anyaoku (Nigeria).

\section{African Development Bank}

Established in 1964 to promote economic and social development in Africa.

Regional Members. (53) Algeria, Angola, Benin, Botswana, Burkina Faso, Burundi, Cameroon, Cape Verde, Central African Republic, Chad, Comoros, Congo (Dem. Rep. of), Congo (Rep. of), Côte d'Ivoire, Djibouti, Egypt, Equatorial Guinea, Eritrea, Ethiopia, Gabon, The Gambia, Ghana, Guinea, Guinea-Bissau, Kenya, Lesotho, Liberia, Libya, Madagascar, Malaŵi, Mali, Mauritania, Mauritius, Morocco, Mozambique, Namibia, Niger, Nigeria, Rwanda, São Tomé e Príncipe, Senegal, Seychelles, Sierra Leone, Somalia, South Africa (Rep. of), Sudan, Swaziland, Tanzania, Togo, Tunisia, Uganda, Zambia, Zimbabwe.

Non-regional Members. (24) Argentina, Austria, Belgium, Brazil, Canada, China, Denmark, Finland, France, Germany, India, Italy, Japan, South Korea, Kuwait, Netherlands, Norway, Portugal, Saudi Arabia, Spain, Sweden, Switzerland, UK, USA.

Within the ADB Group are the African Development Fund (ADF) and the Nigerian Trust Fund (NTF). The ADF, established in 1972, provides development finance on concessional terms to low-income Regional Member Countries which are unable to borrow on the non-concessional terms of the African Development Bank. Membership of the Fund is made up of 24 non-African State Participants and the African Development Bank. The NTF is a special ADB fund created in 1976 by agreement between the Bank Group and the Government of the Federal Republic of Nigeria. Its objective is to assist the development efforts of lowincome Regional Member Countries whose economic and social conditions and prospects require concessional financing.

Official languages: English, French.

Headquarters: 01 BP 1387, Abidjan 01, Côte d'Ivoire.

Website: http://www.afdb.org

email:afdb@afdb.org

President: Donald Kaberuka (Rwanda).

\section{African Export-Import Bank (Afreximbank)}

Established in 1987 under the auspices of the African Development Bank to facilitate, promote and expand intraAfrican and extra-African trade. Membership is made up of three categories of shareholders: Class 'A' Shareholders consisting of African governments, African central banks and sub-regional and regional financial institutions and economic organizations;
Class 'B' Shareholders consisting of African public and private financial institutions; and Class ' $\mathrm{C}$ ' Shareholders consisting of international financial institutions, economic organizations and non-African states, banks, financial institutions and public and private investors.

Official languages: English, French, Arabic, Portuguese. Headquarters: World Trade Center, 1191 Corniche El-Nil, Cairo 11221, Egypt.

Website: http://www.afreximbank.com

President and Chairman of the Board: Jean-Louis Ekra (Côte d'Ivoire).

\section{African Union (AU)}

History. The Fourth Extraordinary Session of the Assembly of the Heads of State and Government of the Organization of African Unity (OAU) held in Sirté, Libya on 9 Sept. 1999 decided to establish an African Union. At Lomé, Togo on 11 July 2000 the OAU Assembly of the Heads of State and Government adopted the Constitutive Act of the African Union, which was later ratified by the required two-thirds of the member states of the Organization of African Unity (OAU); it came into force on 26 May 2001. The Lusaka Summit, in July 2001, gave a mandate to translate the transformation of the Organization of African Unity into the African Union, and on 9 July 2002 the Durban Summit, in South Africa, formally launched the African Union.

Members. Algeria, Angola, Benin, Botswana, Burkina Faso, Burundi, Cameroon, Cape Verde, Central African Republic, Chad, Comoros, Congo (Dem. Rep. of), Congo (Rep. of), Côte d'Ivoire, Djibouti, Egypt, Equatorial Guinea, Eritrea, Ethiopia, Gabon, Gambia, Ghana, Guinea, Guinea-Bissau, Kenya, Lesotho, Liberia, Libya, Madagascar, Malawii, Mali, Mauritania ${ }^{\star}$, Mauritius, Mozambique, Namibia, Niger, Nigeria, Rwanda, Sahrawi Arab Democratic Republic (Western Sahara), São Tomé e Príncipe, Senegal, Seychelles, Sierra Leone, Somalia, South Africa, Sudan, Swaziland, Tanzania, Togo, Tunisia, Uganda, Zambia, Zimbabwe. ${ }^{*}$ Membership suspended Aug. 2005-April 2007.

Aims. The African Union aims to promote unity, solidarity, cohesion and co-operation among the peoples of Africa and African states, and at the same time to co-ordinate efforts by African people to realize their goals of achieving economic, political and social integration.

Activities. The African Union became fully operational in July 2002 , and is working towards establishing the organs stipulated in the constitutive act. These include a Pan-African parliament and a Peace and Security Council (both of which have now been inaugurated), an Economic, Social and Cultural Council (ECOSOC), a Central Bank and a Court of Justice.

Official languages: Arabic, English, French, Ki-Swahili, Portuguese and Spanish.

Headquarters: POB 3243, Addis Ababa, Ethiopia.

Website: http://www.africa-union.org

Chairman: Jakaya Kikwete (Tanzania).

\section{Bank of Central African States (BEAC)}

The Bank of Central African States (Banque des Etats de l'Afrique Centrale) was established in 1973 when a new Convention of 